\section{Birlesik Dunya Arastrma Cypriot Journal of Educational \\ Sciences}

Volume 15, Issue 2, (2020) 282-291

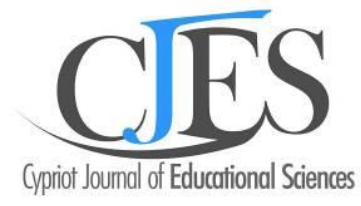

www.cjes.eu

\title{
Relative effect of animated and non-animated powerpoint presentations on physics students' achievement
}

Christian S. Ugwuanyi*, Postdoctoral Fellow, School of Education Studies, Faculty of Education, University of the Free State, Bloemfontein 9300, South Africa. https://orcid.org/0000-0003-2174-3674

Chinedu I. O. Okeke, Host, Professor, and Head, School of Education Studies, Faculty of Education, University of the Free State, Bloemfontein 9300, South Africa. https://orcid.org/0000-0003-3046-5266

Peace A. Nnamani, Department of Science Education, University of Nigeria, Nsukka, Nigeria

Euphemia C. Obochi, Department of Science Education, University of Nigeria, Nsukka, Nigeria

Christian C. Obasi, Department of Science Education, University of Nigeria, Nsukka, Nigeria

\section{Suggested Citation:}

Ugwuanyi, C. S., Okeke, C. I. O., Nnamani, P. A., Obochi, E. C. \& Obasi, C. C. (2020). Relative effect of animated and non-animated powerpoint presentations on physics students' achievement. Cypriot Journal of Educational Science. 15(2), 282-291. https://doi.org/10.18844/cjes.v15i2.4647

Received August 5, 2019; revised January 1, 2020; accepted April 1, 2020.

${ }^{\circ} 2020$ United World Center of Research Innovation and Publication. All rights reserved.

\begin{abstract}
This paper determined the relative effect of animated and non-animated powerpoint (PPT) presentations on students' achievement in physics. A non-equivalent group quasi-experimental research design was adopted for the study, using a sample of 88 senior secondary two students drawn from secondary schools in Nsukka Local Government Area of Enugu State. A 30-item multiple-choice Physics Achievement Test (PAT) was used for data collection. The instrument was both face and content validate. The internal consistency reliability of the items of the PAT was established to be 0.76 using KuderRichardson formula 20, while the estimated temporal stability was obtained to be 0.88 using Pearson's product-moment correlation. The mean was used to answer the research questions while $t$-test of independent samples was used to test the null hypotheses at 0.05 level of significance. The findings of the study revealed that animated PPT significantly enhanced the achievement of students in physics than the non-animated PPT presentation.
\end{abstract}

Keywords: Achievement, powerpoint animation, physics, presentation, relative effect.

*ADDRESS FOR CORRESPONDENCE: Christian S. Ugwuanyi, Postdoctoral Fellow, School of Education Studies, Faculty of Education, University of the Free State, Bloemfontein 9300, South Africa. E-mail address: Ugwuanyics@ufs.ac.za 
Ugwuanyi, C. S., Okeke, C. I. O., Nnamani, P. A., Obochi, E. C. \& Obasi, C. C. (2020). Relative effect of animated and non-animated powerpoint presentations on physics students' achievement. Cypriot Journal of Educational Science. 15(2), 282-291.

https://doi.org/10.18844/cjes.v15i2.4647

\section{Introduction}

Students' performance in physics internal and external examinations has not been encouraging. This is evidenced in the West African Examinations' Council Chief Examiner's reports of students' performance in Physics which showed that out of 685,669 candidates enrolled for the examination in the subject in May/June 2014, less than 30\% had credit pass and above and in May/June 2015 less than $35 \%$ of 658,393 candidates who enrolled for the same examination had credit pass and above. Besides, Erdemir (2009) found that the performance in physics is lower than other science subjects, such as biology and chemistry. This alarming trend has become a great threat to the nation's future and survival in terms of science and its benefits.

This poor performance of students in physics can be attributed to the lack of teachers' use of innovative teaching methods and strategies in the 21st-century classroom. The literature shows that information communication technology has a significant impact on students' achievement, especially in this 21st century world. In technology-aided education, visual materials such as powerpoint (PPT) animations, animated pictures and multimedia software have great importance (Aksoy, 2013). PPT is a soft way of presenting lecture materials to the students to appeal to the visual sense of the students and attract their attention. PPT Instruction Strategy is one aspect of computer-based instruction that helps any educational level to convey information better and allows students to proceed at a comfortable learning rate (Osigwelem, 2005).

The presentation can be animated or non-animated. According to Clark and Mayer (2003), animation refers to a computerised simulation of processes using images to structure a synthetic motion picture and adding printed text, charts, maps, static graphics and self-motivated graphics. When used essentially as a form of entertainment, an animation can be a cartoon, but in this study, we focused on the potential of animation as an educational tool (Hamzat, Bello \& Abimbola, 2017). According to Hamzat et al. (2017), different categories of images with text have diverse functions in creating mental models as a replacement for simply receiving the knowledge. The animation that combines audio and visual features may help in the course of encoding information, storing it into lasting memory and the recovery process (Paivio as cited in Hamzat et al., 2017). Animations facilitate descriptive and procedural learning with an assurance of enhanced performance when applied for instructions over contemporary means (Mayer, 2001).

Several studies have revealed the effect of PPT animation on students' achievement. Ugwuanyi et al. (2019) found that PPT presentation had a significant effect on students' achievement in physics and mathematics. Bamidele and Yoade (2017) found that the animation combined with narration and onscreen text $(A+N+T)$ package produced the highest mean score (mean $=16.67)$, followed by the Animation combined with Narration $(A+N)$ package (mean $=15.42)$ and the lowest mean score (mean $=12.75$ ) was recorded for the conventional teaching method. Erdemir (2011) found that the students at the experimental group who participated in lectures supported by PPPs had higher grades than the control group who were solely taught through traditional presentations. Aksoy (2013) found that the computer animation technique is more effective than traditional teaching methods in terms of enhancing students' achievement. Abdul, Sana and Arabella (2017) found a positive effect of animation on learning of physics. Findings of Adegbija and Falode (2014) revealed that students taught Physics using Animation-based CamStudio Instructional Package performed significantly better than those taught using the conventional lecture method. Computer-assisted instructional package significantly improved students' achievement in practical biology (Hamzat et al., 2017). Findings of other studies, such as Abidoye and Omotunde (2015), Ayotola and Abiodun (2010), Gambari, Falode and Adegbenro (2014) and Salisu (2015) revealed a significant effect of computer-assisted instruction on students' achievement in different subjects excluding physics. King-Dow and Shih-Chuan (2015) found that animations contributed much in learning the results of students' performance which uplifted students' physics concepts understanding and learning attitudes indicated by different variances of gender and dispositions. 
Ugwuanyi, C. S., Okeke, C. I. O., Nnamani, P. A., Obochi, E. C. \& Obasi, C. C. (2020). Relative effect of animated and non-animated powerpoint presentations on physics students' achievement. Cypriot Journal of Educational Science. 15(2), 282-291.

https://doi.org/10.18844/cjes.v15i2.4647

Moreover, findings of Anigbo and Orie (2018) revealed that the experimental group taught with Microsoft PPT Instruction Strategy obtained a higher mean achievement score than the control group in the post COSAT but the difference was not significant. Ezza, Alhuqail and Elhussain (2019) found that instructional technology could significantly enhance learners' composing skills. Ruzicka and Milova (2019) found that the use of video analysis in providing feedback has a positive effect on the process of downhill skiing skills acquisition.

Despite the inconsistencies in the findings of the previous studies on the subject matter, literature is scarce on the effect of animated and non-animated PPT presentations on students' achievement in physics, especially in the Nigerian context. This gap in literature necessitated the present study which determined the relative effect of animated and non-animated PPT presentations on students' achievement in physics in Nsukka Education zone of Enugu State.

\subsection{Objectives of the study}

The following objectives were sought for the study.

1. Determine the effect of animated and non-animated PPT on mean achievement scores of students at the pretest.

2. Determine the effect of animated and non-animated PPT on mean achievement scores of students at the posttest

3. Determine the effect of animated and non-animated PPT on mean achievement scores of students at the follow-up measure.

\subsection{Hypotheses}

The following hypotheses were tested at $5 \%$ probability levels

$\mathrm{Ho}_{1}$ : There is no significant difference in mean achievement scores of animated and non-animated groups students at the pretest.

Ho: $_{2}$ : Animated and non-animated PPT presentations had no significant differential effects on students' achievement in physics at posttest.

$\mathrm{Ho}_{3}$ : Animated and non-animated PPT presentations had no significant differential effects on students' achievement in physics at follow-up measure.

\section{Methods}

\subsection{Research design}

The study adopted a non-equivalent group quasi-experimental research design. According to Creswell (2014), quasi-experiment involves a researcher assigning, but not randomly, participants to groups because the experimenter cannot artificially create groups for the experiment. This was to enable the researchers to experiment using intact classes of students without disrupting the school's normal academic program.

\subsection{Participants}

The sample size for the study was 88 senior secondary, 2 students out of 3,635 senior secondary, 2 Physics Students in 30 public Secondary Schools in Nsukka Local Government Area of Enugu State. The sample was purposively drawn from two co-educational schools in Nsukka Education zone of Enugu State, Nigeria. The students in the two intact classes were assigned to experimental 1 (43) and experimental group 2 (45) using a simple random sampling technique as shown in Figure 1. 
Ugwuanyi, C. S., Okeke, C. I. O., Nnamani, P. A., Obochi, E. C. \& Obasi, C. C. (2020). Relative effect of animated and non-animated powerpoint presentations on physics students' achievement. Cypriot Journal of Educational Science. 15(2), 282-291.

https://doi.org/10.18844/cjes.v15i2.4647

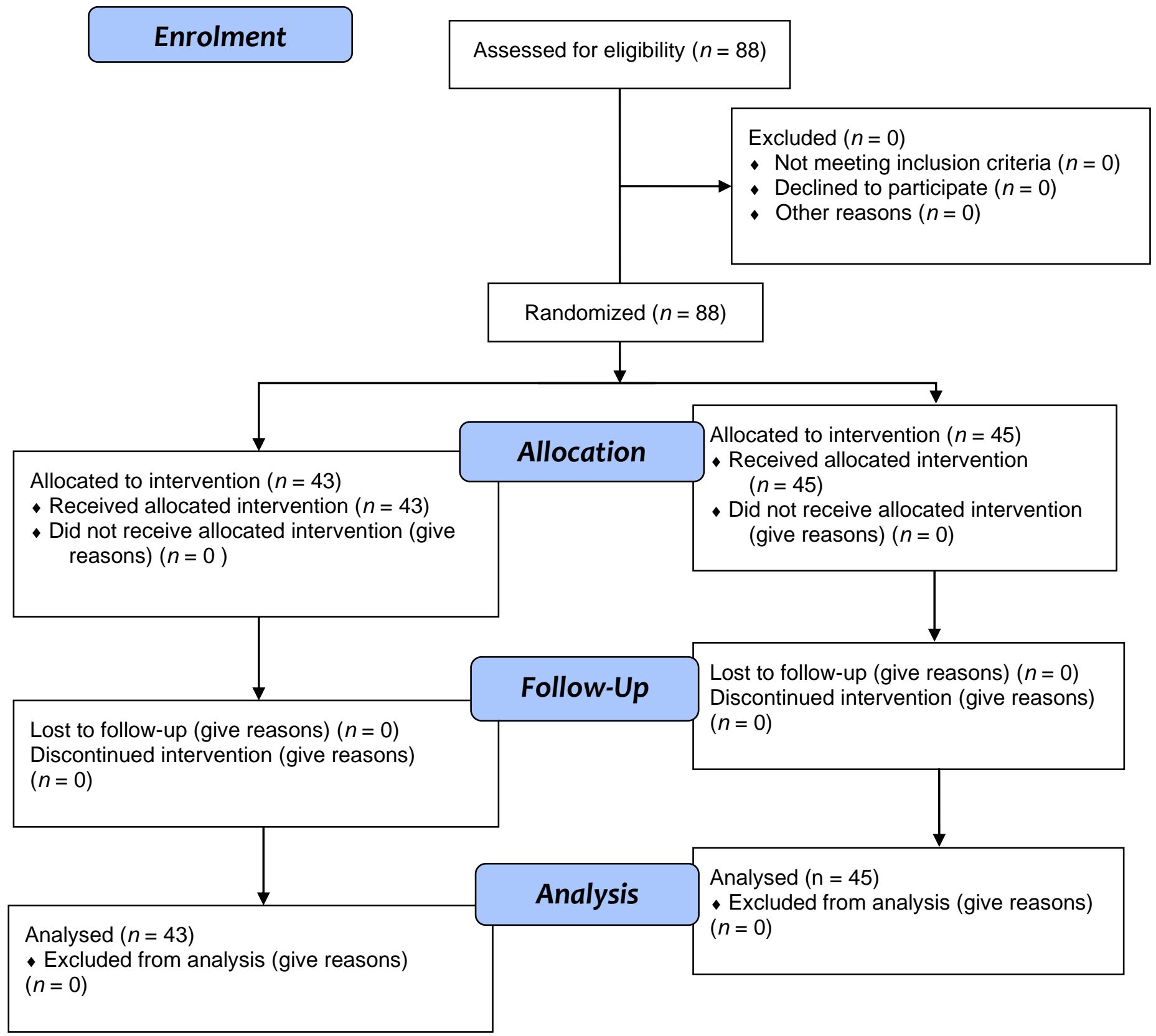

Figure 1. Flow diagram of the sampled participants

\subsection{Instrument for data collection}

Physics Achievement Test (PAT) developed by the researchers was used to collect the data. The instrument has 30 multiple-choice test items. PAT has two sections (A and B). Section A elicited information on the students' names, class and sex, while section B elicited information on the achievement of the student in the content area. Each of the multiple-choice test items had four options (A-D). For each item, only one of the four options is the correct answer. The items were developed to reflect the concepts treated and about the objectives of the lesson on which instruction was based. 
Ugwuanyi, C. S., Okeke, C. I. O., Nnamani, P. A., Obochi, E. C. \& Obasi, C. C. (2020). Relative effect of animated and non-animated powerpoint presentations on physics students' achievement. Cypriot Journal of Educational Science. 15(2), 282-291.

https://doi.org/10.18844/cjes.v15i2.4647

\subsection{Development of the learning package}

PPT presentations with animation package and without animation packages were developed by the researchers. The need for the researchers to make a computer package is based on the fact that PPT presentation packages are not common. The PPT Presentation package utilises custom animation and it is presented in slides. The production of the package was carried out with the help of a team of professionals and specialists, including system programmers and instructional designers who are the researchers. The main menu consists of the background, introduction, the topic and the unit of the topic and finally exit button. PPT presentation was done in two ways, one with animation and the other without animation.

\subsection{Validation of the instrument and PPT package}

The developed PPT presentation package and the 30 items objective physics achievement test instrument was subjected to face validation by three experts. These include one (1) expert from measurement and evaluation and two (2) experts from physics Education all in the Department of Science Education, University of Nigeria Nsukka. The experts were requested to specifically examine the test items along with the following criteria, clarity of the questions asked, appropriateness of the questions to the students' level of understanding and experience. The constructive criticisms of the validators were used to modify the instrument as well as the package.

\subsection{Reliability of the instrument}

A trial testing was conducted to ascertain the reliability of the objective test items. The trial testing was carried out using 20 students who were randomly sampled from Community Secondary School Obollo-Afor using a simple random sampling technique (hat and draw). The data obtained were analysed using Kuder-Richardson formula 20. An internal consistency reliability coefficient of 0.76 was obtained while a test-retest reliability index of 0.88 was obtained using Person's product-moment correlation.

\subsection{Experimental procedure}

Before the commencement of the experiment, the researchers conducted training for the research assistants. They were briefed on how to carry on with the experiment. PAT was then administered to the students before the commencement of the treatment as a pretest. The data obtained by students served as pretest scores for the study. After the pretest, treatment was administered to the students in each of the groups which lasted for 4 weeks. The first group was taught with animation after which the students attempted some multiple-choice objective questions. The second group was taught without animation after which the students attempted the same multiple questions. At the end of the treatment, posttest was administered on the two groups. The test was conducted at the same time and the scripts were collected immediately for marking. After 2 months of the treatment, a follow-up measure or assessment was done by the researchers on the same participants.

Finally, the pre-test, post-test and follow-up scores were subjected to data analysis. For the scoring purpose, each of the thirty items in PAT was scored one mark making a total of 30 marks.

\subsection{Method of data analysis}

Data collected were analysed using mean and $t$-test of independent samples. Mean was used to answer the research questions while $t$-test of independent samples was used to test the hypotheses formulated for the study at $p \leq 0.05$ probability level. 
Ugwuanyi, C. S., Okeke, C. I. O., Nnamani, P. A., Obochi, E. C. \& Obasi, C. C. (2020). Relative effect of animated and non-animated powerpoint presentations on physics students' achievement. Cypriot Journal of Educational Science. 15(2), 282-291.

\section{DESIGN}

PRE-TEST, POST-TEST NON-EQUIVALENT CONTROL GROUP QUASI EXPERIMENT

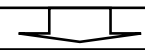

TARGET POPULATION

3,635 SS 2 STUDENTS IN NSUKKA EDUCATION ZONE

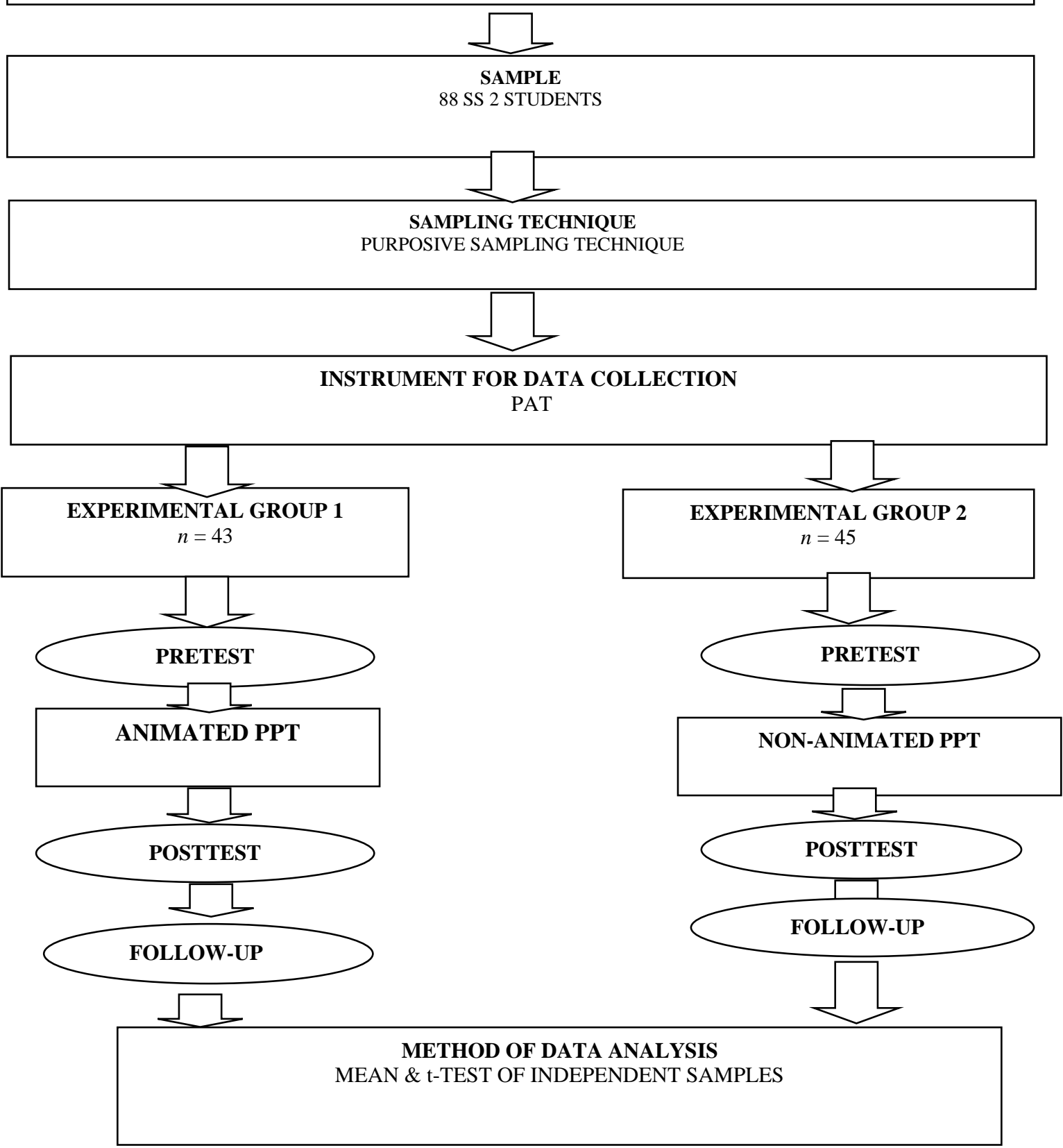

Figure 2. Schematic representation of the methods 
Ugwuanyi, C. S., Okeke, C. I. O., Nnamani, P. A., Obochi, E. C. \& Obasi, C. C. (2020). Relative effect of animated and non-animated powerpoint presentations on physics students' achievement. Cypriot Journal of Educational Science. 15(2), 282-291.

https://doi.org/10.18844/cjes.v15i2.4647

\section{Results}

Table 1. $T$-test of independent samples for the differences in the mean achievement scores of physics students at pretest, posttest and follow-up measures

\begin{tabular}{lccccccc}
\hline \multicolumn{1}{c}{ Treatment } & Time & $\boldsymbol{N}$ & Mean & SD & df & $\boldsymbol{t}$ & $\boldsymbol{P}$ \\
\hline Animated PPT & Pretest & 43 & 15.31 & 3.50 & 86 & 0.493 & 0.624 \\
Non-animated PPT & & 45 & 14.98 & 2.80 & & & \\
Animated PPT & Posttest & 43 & 23.92 & 5.63 & 86 & 2.629 & 0.010 \\
Non-animated PPT & & 45 & 20.93 & 5.05 & & & \\
Animated PPT & Follow-up & 43 & 24.26 & 5.80 & 86 & 2.781 & 0.007 \\
Non-animated PPT & & 45 & 21.02 & 5.13 & & & \\
\hline
\end{tabular}

Table 1 shows that the mean achievement score of the students taught physics using animated PPT $(M=15.31, \mathrm{SD}=3.50)$ did not differ significantly from those taught using non-animated PPT $(M=14.98, \mathrm{SD}=2.80), t(86)=0.493, p=0.624$. At the posttest, the mean achievement score of the students taught physics using animated PPT $(M=23.92, \mathrm{SD}=5.63)$ differed significantly from those taught using non-animated PPT $(M=20.93, \mathrm{SD}=5.05), t(58)=2.629, p=0.010$. Similarly, at the follow-up measure, the mean achievement score of the students taught physics using animated PPT $(M=24.26, S D=5.80)$ differed significantly from those taught using non-animated PPT $(M=21.02$, SD $=5.13), t(86)=2.781, p=0.007$. This implies that animated PPT had a significant effect on students' achievement in physics than the non-animated PPT.

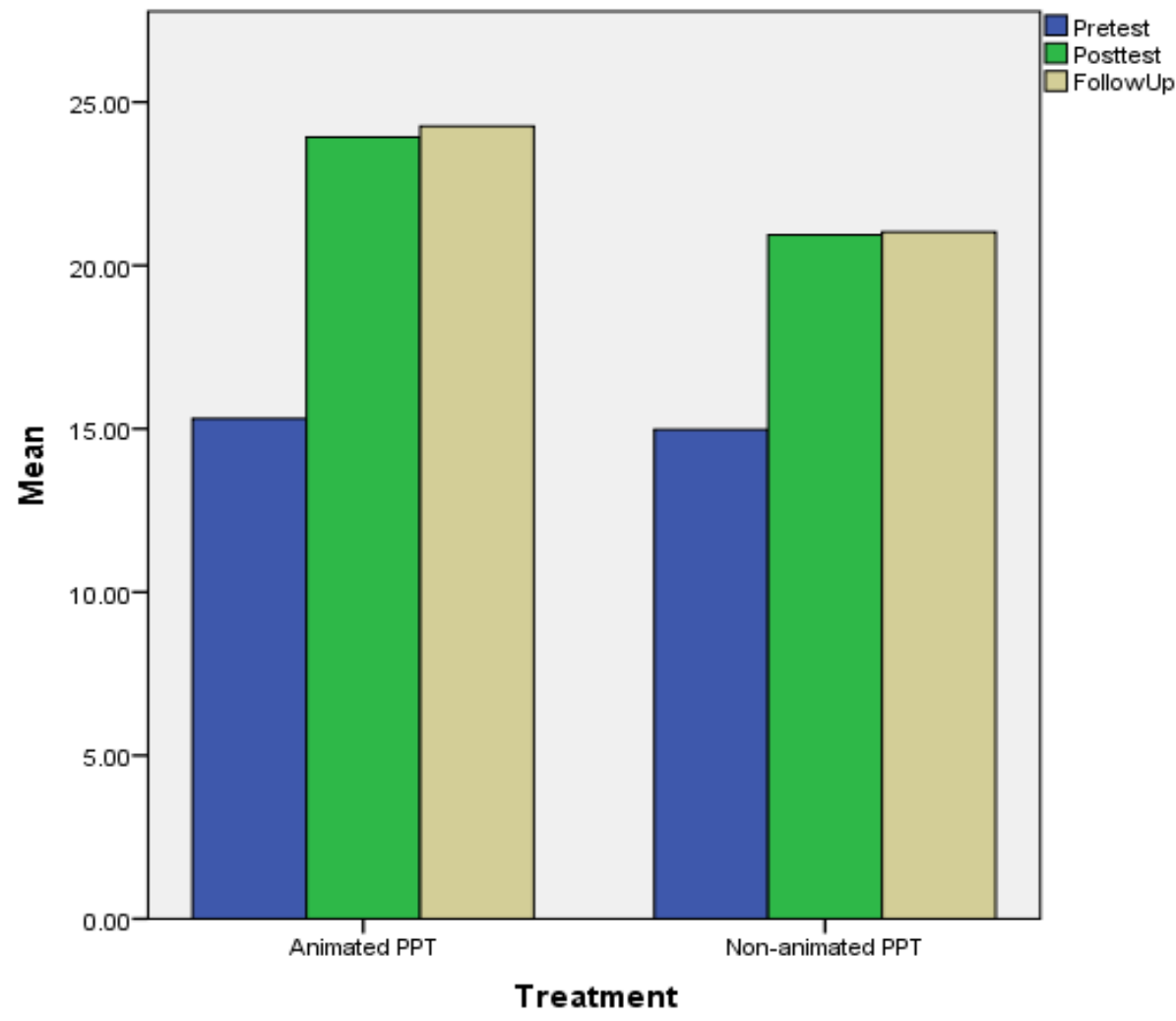

Figure 3. Graph of the pretest, posttest and follow-up mean achievement scores of the participants in experimental and control groups 
Ugwuanyi, C. S., Okeke, C. I. O., Nnamani, P. A., Obochi, E. C. \& Obasi, C. C. (2020). Relative effect of animated and non-animated powerpoint presentations on physics students' achievement. Cypriot Journal of Educational Science. 15(2), 282-291.

https://doi.org/10.18844/cjes.v15i2.4647

\section{Discussion of the findings}

The findings of the study revealed that the students taught physics using PPT presentations with animation achieved significantly higher than those taught using PPT presentations without animation at both posttest and follow-up measures. This implies that animated PPT had a significant effect on students' achievement in physics than the non-animated PPT. These findings may have resulted in this way because of the nature of animated PPT. The animated PPT has the inherent feature of attracting the attention of the users thereby making them focused. During the treatment period, the researchers noticed that those who were taught using animated PPT were more participatory than those taught with non-animated PPT. This may have resulted in their significant achievement than their counterparts in the non-animated PPT group. Buttressing this point, Abdul et al. (2017) opined that the use of animations in teaching generate and sustain attention, cheer in the thinking of students and assist for conceptual understanding. These findings are in line with the findings of other related studies. For instance, Ugwuanyi et al. (2019) found that PPT presentation had a significant effect on students' achievement in physics and mathematics. Bamidele and Yoade (2017) found that the animation combined with narration and on-screen text $(A+N+T)$ package produced the highest mean score (mean $=16.67)$, followed by the Animation combined with Narration $(A+N)$ package (mean $=15.42)$ and the lowest mean score $($ mean $=12.75)$ was recorded for the conventional teaching method.

Erdemir (2011) found that the students at the experimental group who participated in lectures supported by PPPs had higher grades than the control group who were solely taught through traditional presentations. Aksoy (2013) found that the computer animation technique is more effective than traditional teaching methods in terms of enhancing students' achievement. Abdul et al. (2017) found a positive effect of animation on learning of physics. Findings of Adegbija and Falode (2014) revealed that students taught Physics using Animation-based CamStudio Instructional Package performed significantly better than those taught using the conventional lecture method. Computerassisted instructional package significantly improved students' achievement in practical biology (Hamzat et al., 2017). Findings of other studies, such as Abidoye and Omotunde (2015), Ayotola and Abiodun (2010), Gambari et al. (2014) and Salisu (2015) revealed a significant effect of computerassisted instruction on students' achievement in different subjects excluding physics. King-Dow and Shih-Chuan (2015) found that animations contributed much in learning the results of students' performance which uplifted students' physics concepts understanding and learning attitudes indicated by different variances of gender and dispositions. The findings of this study validated many characteristics of integrated animations and animated environments which contributed much to students' scientific learning competence and proficiency (Kiboss, 2002; Su, 2008a; 2008b, 2011, 2013; Tao, 2004). Ezza et al. (2019) found that instructional technology could significantly enhance learners' composing skills. Ruzicka and Milova (2019) found that the use of video analysis in providing feedback has a positive effect on the process of downhill skiing skills acquisition. Ejimonye et al. (2020) found that 2D animation technique proved to be significantly effective in enhancing students' motivation in quantitative contents of economics. Ugwuanyi et al. (2019) found that flipped classroom instructional technology was effective in enhancing the achievement of physics students at both post-test and follow-up measurements.

This study has been able to add to the contribution to the knowledge in the area of physics education by proving empirically the effectiveness of animated PPT over non-animated PPT on the achievement of students in physics. This is unlike other studies that used either animated versus lecture method or animated versus non-animated but different subject areas like geography, biology, chemistry and so on. 
Ugwuanyi, C. S., Okeke, C. I. O., Nnamani, P. A., Obochi, E. C. \& Obasi, C. C. (2020). Relative effect of animated and non-animated powerpoint presentations on physics students' achievement. Cypriot Journal of Educational Science. 15(2), 282-291.

https://doi.org/10.18844/cjes.v15i2.4647

\subsection{Limitations of the findings}

The findings of this study may be limited by, such factors as gender, cultural orientation and location. In this study, the researchers were not able to check for the moderating influence of those possible moderators, thereby limiting the generalisability of the findings of the study. Thus, further researchers can replicate this study by considering those possible moderators.

\section{Conclusion and recommendations}

This study has proven the efficacy of animated PPT presentation on students' achievement in physics. This may be because, during the treatment periods, the students who were in the animated PPT group were very active in the learning process than those in the non-animated PPT group. Hence, the application of animated PPT enhances students' achievement in physics more than the nonanimated PPT. In order words, adequate implementation of animated PPT presentation by physics teachers will lead to enhanced students' achievement in physics. It was, therefore, recommended that:

1. An adequate arrangement should be made by the school authorities for the full implementation of animated PPT for physics instruction by the teachers.

2. Physics teachers should also be made to undergo intensive training on how to use animated PPT to present their physics instructions.

\section{References}

Abdul, R., Sana, S. \& Arabella, B. (2017). Use of animations to improve learning of physics education. International Journal of Social Science and Humanities Research, 5(4), 290-293. Retrieved from DOI: $10.2991 /$ icst-18.2018.225

Abidoye, J. A. \& Omotunde, C. T. (2015). Effects of computer animation package on senior secondary school students' academic achievement in geography in Ondo state, Nigeria. Journal of Teaching and Teacher Education, 3(2). DOI: 10.12785/itte/030202

Adegbija, M. V. \& Falode, C. O. (2014). Effects of animation-based camstudio physics instruction on secondary school students' performance in Minna, Nigeria. European Scientific Journal, 10(13), 2014. http://dx.doi.org/10.12785/jtte/030202

Aksoy, G. (2013). Effect of computer animation technique on students' comprehension of the "solar system and beyond" unit in the science and technology course. Mevlana International Journal of Education (MIJE), 3(1), 40-46. Retrieved from http://mije.mevlana.edu.tr/

Anigbo, L. C \& Orie, M. J. (2018). Effect of powerpoint instruction on students' academic achievement in computer science (database management system) in Colleges of Education in Rivers State. Computer Engineering and Intelligent Systems, 9(1). Retrieved from www.iiste.org

Ayotola, A. \& Abiodun, S. (2010). Computer animation and the academic achievement of Nigerian senior secondary school students in biology. Journal of the Research Center for Education Technology (RCET), 6(2), 148-161.

Bamidele, E. F. \& Yoade, F. B. (2017). Effects of modes of computer animation instructional packages on students' achievement in Osun state secondary schools' Biology. International Journal of Innovation and Research in Educational Sciences, 4(4), 2349-5219.

Clark, R. C. \& Mayer, R. E. (2003). E-learning and the science of instruction. San Franciso, CA: John Wiley \& Sons.

Creswell, J. W. (2014). Research design: quantitative and qualitative mixed methods approaches (4th ed.). Thousand Oaks, CA: Sage.

Ejimonye, J.C., Onuoha, J.C., Ugwuanyi, C.S., Eneogu, N.D., Ugwuanyi, B.E \& Ogbuehu, S.N (2020). Effectiveness of Two-Dimensional Animation Technique in Enhancing Students' Motivation in Quantitative Economics 
Ugwuanyi, C. S., Okeke, C. I. O., Nnamani, P. A., Obochi, E. C. \& Obasi, C. C. (2020). Relative effect of animated and non-animated powerpoint presentations on physics students' achievement. Cypriot Journal of Educational Science. 15(2), 282-291.

https://doi.org/10.18844/cjes.v15i2.4647

Concepts. International Journal of Future Generation Communication and Networking (IJFGCN), 13(1):27-38.

Erdemir, N. (2009). Determining students' attitude towards physics through problem solving strategy. AsiaPacific Forum on Science Learning and Teaching, 10(2). http://www.ied.edu.hk/apfslt

Erdemir, N. (2011). The effect of powerpoint and traditional lectures on students' achievement in physics. Journal of Turkish Science Education, 8(3), 176-189.

Ezza, E.-S., Alhuqail, E. \& Elhussain, S. (2019). Technology-based instructional intervention into an EFL writing classroom. Cypriot Journal of Educational Science, 14(4), 507-519. doi:10.18844/cjes.v11i4.3904

Gambari, A. I., Falode, C. O. \& Adegbenro, D. A. (2014). The effectiveness of computer animation and geometrical instructional model on mathematics achievement and retention among junior secondary school students. European Journal of Science and Mathematics Education, 2(2), 127-146.

Hamzat, A., Bello, G. \& Abimbola, I. O. (2017). Effects of computer animation instructional package on students' achievement in practical biology. Cypriot Journal of Educational Science, 12(4), 218-227. doi:10.18844/cjes.v11i4.1217

Kiboss, J. K. (2002). Impact of a computer-based physics instruction program on pupils' understanding of measurement concepts and methods associated with school science. Journal of Science Education and Technology, 11, 193-198.

King-Dow, S. \& Shih-Chuan, Y. (2015). Effective assessments of integrated animations to explore college students' physics learning performances. Procedia-Social and Behavioral Sciences, 176, 588-595. doi:10.1016/j.sbspro.2015.01.514 ScienceDirect IETC 2014.

Mayer, R. E. (2001). Multimedia learning. New York, NY: Cambridge University Press.

Ruzicka, I. \& Milova, J. (2019). Increasing the efficiency of motor learning with the help of video analysis. Cypriot Journal of Educational Science, 14(4), 723-730. DOI: 10.18844/cjes.v11i4.1217

Salisu, A. (2015). Impact of animated-media strategy on achievement, retention and interest among secondary school geography students in weather concepts, Kastina State, Nigeria (Unpublished Masters thesis). Department of Science Education, Ahmadu Bello University, Zaria, Nigeria.

Su, K. D. (2008a). An integrated science course designed with information communication technologies to enhance university students' learning performance. Computers and Education, 51, 1365-1374.

$\mathrm{Su}, \mathrm{K}$. D. (2008b). The effects of a chemistry course with integrated information communication technologies on university students' learning and attitudes. International Journal of Science and Mathematics Education, 6, 225-249.

$\mathrm{Su}$, K. D. (2011). An intensive ICT-integrated environmental learning strategy for enhancing student performance. International Journal of Environmental and Science Education, 6(1), 39-58.

Su, K. D. (2013). Validity of problem-solving skills: exploring dynamic reaction figures in acid and base chemical learning. Journal of Computer Engineering Informatics, 1(1), 1-12.

Tao, P. K. (2004). Developing understanding of image formation by lenses through collaborative learning by multimedia computer-assisted learning programs. International Journal of Science Education, 20, 1171-1197.

Ugwuanyi, C.S., Nduji, C.C., Gana, C.S., Nwajiuba, C.A., Ene, C.U., Okeke, A.O., Eseadi, C., \& Okeke, C.F. (2019). Effectiveness of Flipped Classroom Instructional Technology Model in Enhancing Students' Achievement in Physics. International Journal of $u$ - and e- Service, Science and Technology, 12(4), 37-46. http://article.nadiapub.com/IJUNESST/vol12 no4/4.html

Ugwuanyi, C. S., Ugwuanyi, C. C., Ezenwa-Nebife, D. C., Gana, C., Ene, C., Oguguo, B. C., ... Agah, J. J. (2019). Assessment of the efficacy of information and communication technology tool on achievement of students in physics and mathematics: a case of repeated measures. Journal of Engineering and Applied Sciences, 14(13), 4541-4546. doi:10.36478/jeasci.2019.4542.4546 